\title{
Rancangan Sistem Informasi Pemesanan Transportasi dan Sarana Ibadah ke Pura
}

\author{
Ni Putu Ayu Laksmi Purwati \\ Telkom University; \\ Email: laksmipurwati@student.telkomuniversity.ac.id
}

\begin{abstract}
Penulisan paper ini bertujuan untuk membuat rancangan suatu sistem informasi yang dapat digunakan untuk menyelesaikan permasalahan sehari-hari, dimana dalam kasus ini adalah dalam melakukan ibadah. Indonesia merupakan negara yang mewajibkan penduduknya untuk memeluk satu agama, sehingga dengan demikian semua warga negara Indonesia adalah orang yang beragama. Salah satu kewajiban yang seharusnya dijalankan sebagai seseorang yang memeluk agama adalah ibadah. Jarak Pura dari Telkom University terbiilang cukup jauh, selain itu mahasiswa juga memiliki kendala pada transportasi serta sarana untuk persembahyangan. Maka dari itu untuk dapat menjawab permasalahan yang terjadi saya mengusulkan sistem informasi berbasis website yang nantinya dapat dikelola bersama dengan unit kegiatan mahasiswa Keluarga Mahasiswa Hindu Telkom University.
\end{abstract}

Keywords: Reservation system, Information system, Sistem pemesanan

\section{Introduction}

\subsection{Business case}

Ibadah merupakan salah satu hal yang tidak wajib untuk dilakukan, namun sebaiknya dilaksanakan. Cukup jauhnya jarak dari kampus ke Pura (tempat ibadah umat Hindu) serta keterbatasan transportasi mahasiswa menyebabkan hanya sebagian kecil mahasiswa umat Hindu yang dapat melakukan ibadah di hari-hari suci. Selain itu keterbatasan mahasiswa untuk menemukan sarana persembahyangan juga menjadi kendala lainnya. Melihat hal tersebut maka salah satu unit kegiatan mahasiswa yang bergerak di bidang keagamaan yaitu Keluarga Mahasiswa Hindu Telkom University berupaya untuk mengakomodasi transportasi dan juga sarana persembahyangan yang dibutuhkan saat hari-hari suci berlangsung, sehingga mahasiswa dapat melakukan ibadah di Pura. Melihat dari masih kurang efektifnya sistem informasi saat ini, maka saya mengusulkan sistem informasi baru yang menggunakan website, dimana nantinya mahasiswa dapat melakukan pemesanan untuk transportasi dan sarana persembahyangan langsung pada website tersebut. Adapun tolok ukur dari keberhasilan sistem informasi ini nantinya adalah dengan adanya peningkatan jumlah mahasiswa yang melakukan ibadah di Pura saat hari suci berlangsung.

\subsection{System Requirement}

Dalam pembuatan sistem informasi ini dibutuhkan data flow diagram yang terdiri dari 3 level $(0,1$, dan 2) dan entity flow diagram yang dijadikan acuan dalam pembuatan website nantinya. Adapun fitur yang akan disediakan oleh website yang dibuat nanti adalah fitur pemesanan. Setiap mahasiswa yang telah melakukan sign up akan memiliki user ID masing-masing, dengan user ID yang sudah terdaftar maka mereka akan dapat melakukan pemesanan untuk transportasi dan juga sarana persembahyangan sesuai dengan hari suci. Untuk pemesanan ini juga bisa dilakukan sejak jauh hari. Sistem informasi ini akan dirancang dengan menggunakan software Ms. Access dengan fitur-fitur yang terdiri atas form, report, dan database. 


\section{Penjelasan Singkat Terkait Metode}

Metode yang digunakan dalam merancang sistem informasi ini adalah metode model waterfall. Model waterfall atau yang biasa juga disebut model sequential linier adalah metode pengembangan sistem informasi yang paling tua dan sederhana. Model ini cocok untuk pengembangan perangkat lunak yang tidak berubah-ubah yang menyediakan pendekatan alur hidup perangkat lunak secara sequential atau berurutan mulai dari tahap analisis kebutuhan perangkat lunak, desain, pembuatan kode program, pengujian, dan pendukung atai pemeliharaan.

Adapun kelebihan dari model ini adalah kualitas dari sistem yang dihasilkan akan baik, karena dilakukan secara bertahap. Selain itu dokumen pengembangan sistem juga terorganisir karena setiap fase harus diselesaikan secara tuntas sebelum melangkah ke fase atau tahapan berikutnya.

Untuk kekurangan model ini yaitu diperlukan manajemen yang baik karena proses pengembangan tidak dapat dilakukan secara berulang sebelum terbentuk suatu produk, selain itu kesalahan kecil akan menjadi masalah yang besar jika tidak diketahui sejak awal pengembangan.

\section{Proses Perhitungan}

\subsection{System Design}

Dalam sistem ini terdiri dari empat peran yaitu sistem informasi, mahasiswa anggota $\mathrm{KMH}$, pengurus $\mathrm{KMH}$, pengurus Pura, dan Pemilik transportasi (angkot). Pertama mahasiswa akan melakukan login pada website, setelah login berhasil maka sistem akan menampilkan form pemesanan. Mahasiswa kemudian mengisi form pemesanan yang terdiri dari pengisian identitas pemesan dan jumlah pemesanan fasilitas yang diinginkan baik itu untuk angkot ataupun canang. Setelah itu sistem akan melakukan kalkulasi dan menampilkan total biaya yang harus dibayarkan oleh pemesan. Jika sudah maka pemesan dapat meng-klik "make order" dan melakukan logout, sementara jika pemesan ingin melakukan pemesanan lainnya maka dapat meng-klik "create new order" dan mengisi form seperti sebelumnya.

Sistem kemudian mengirimkan data pemesanan kepada pengurus $\mathrm{KMH}$ bagian akomodasi dan transportasi, setelah itu pihak pengurus $\mathrm{KMH}$ akan menghubungi pengurus pura untuk melakukan pemesanan sarana ibadah (canang) dan menghubungi pemilik angkot untuk melakukan pemesanan transportasi (angkot). Setelah itu pengurus $\mathrm{KMH}$ akan mengirimkan reminder kepada mahasiswa anggota $\mathrm{KMH}$ agar tidak lupa untuk datang tepat waktu pada titik kumpul yang telah ditentukan dengan membawa uang tunai sesuai dengan total payment yang diinformasikan.

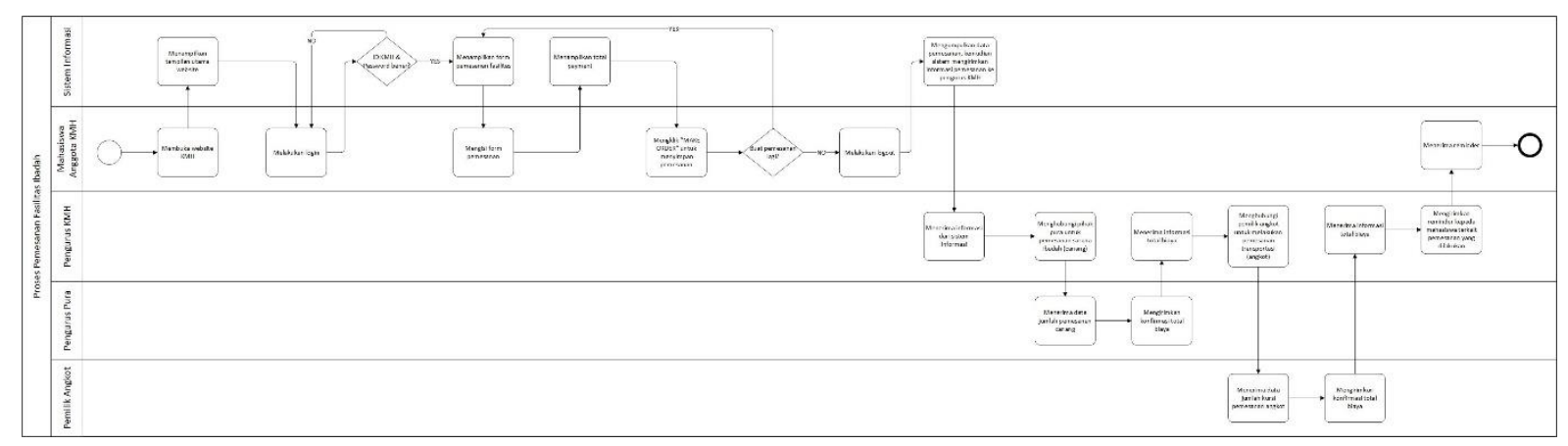

Figure 1 Proses Bisnis Organisasi 


\subsection{Data Flow Diagram (DFD)}

Data flow diagram menunjukkan aliran data yang berlangsung pada sistem informasi, dalam kasus ini aliran data tersebut memiliki 3 level. Pada level 0 menunjukkan aliran data pada sistem informasi pada keseluruhan sistem. Pada level 1 menunjukkan aliran data pada sistem informasi yang lebih rinci dan pada level 2 menunjukkan aliran data pada setiap fitur yang terdapat pada sistem informasi.

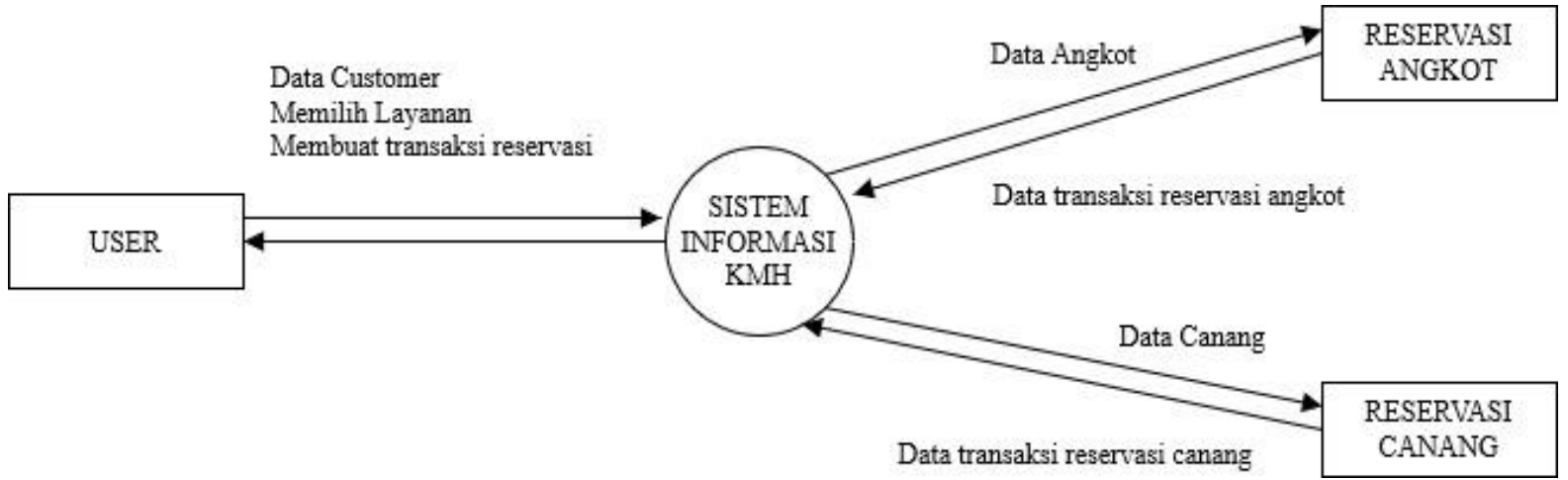

Figure 2 DFD Level 0

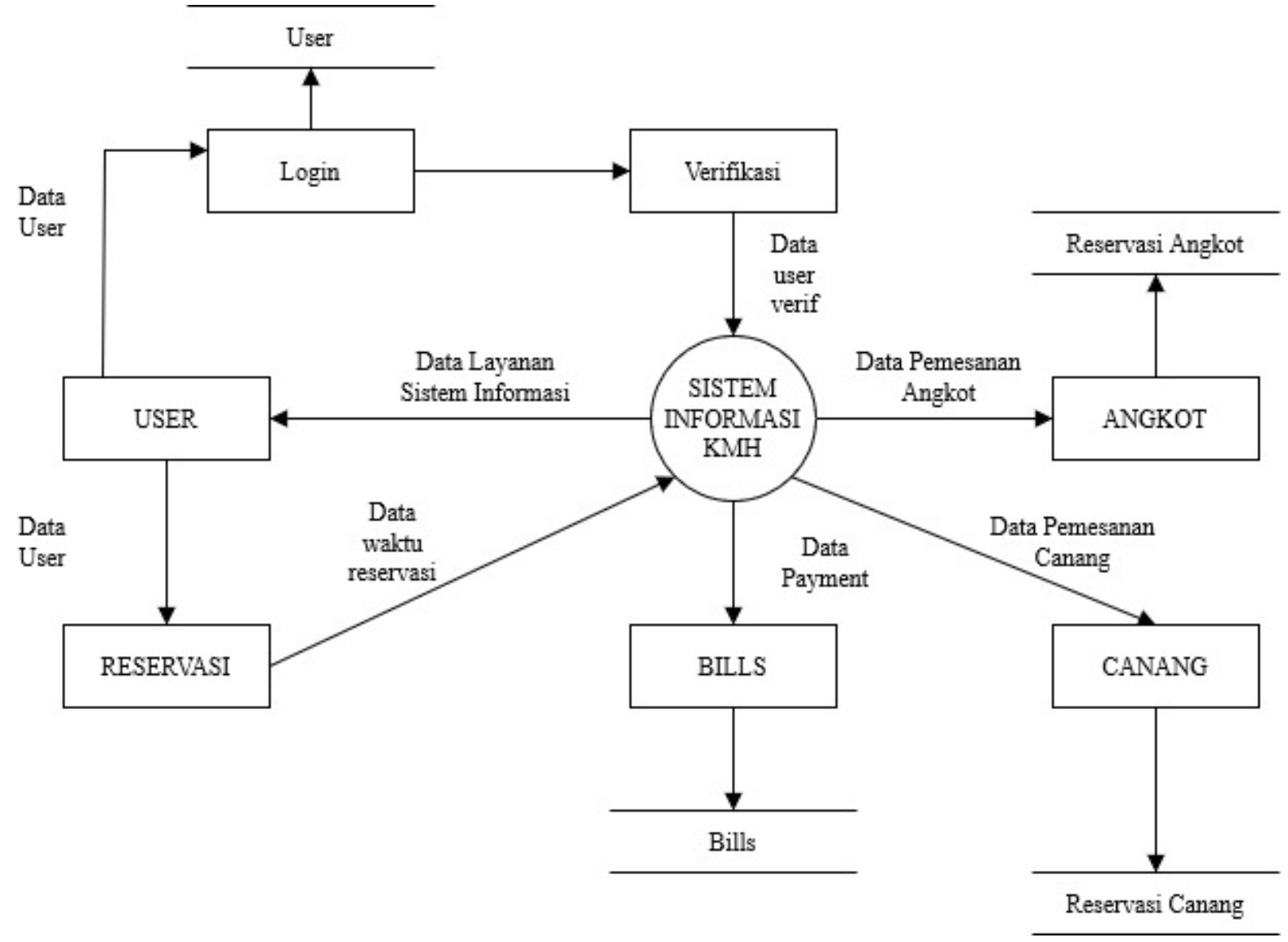

Figure 3 DFD Level 1 


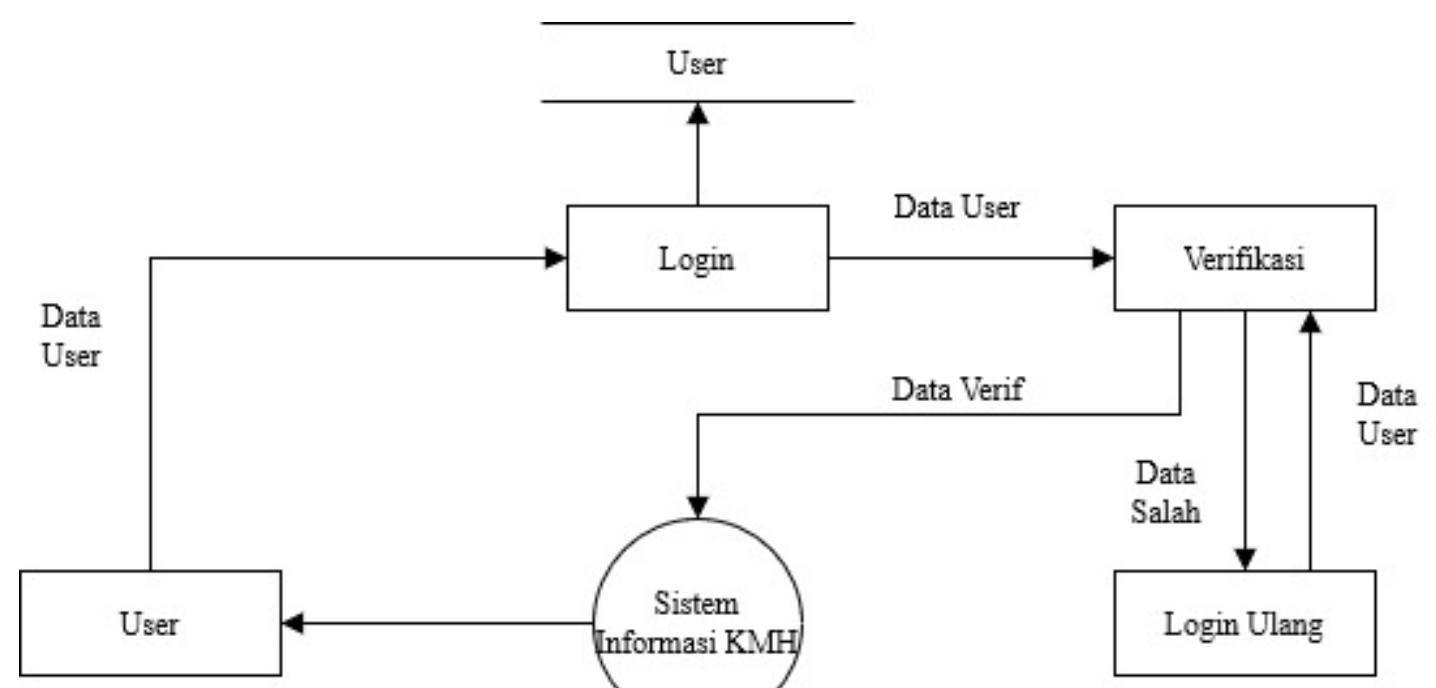

Figure 4 DFD Level 2 - Log in
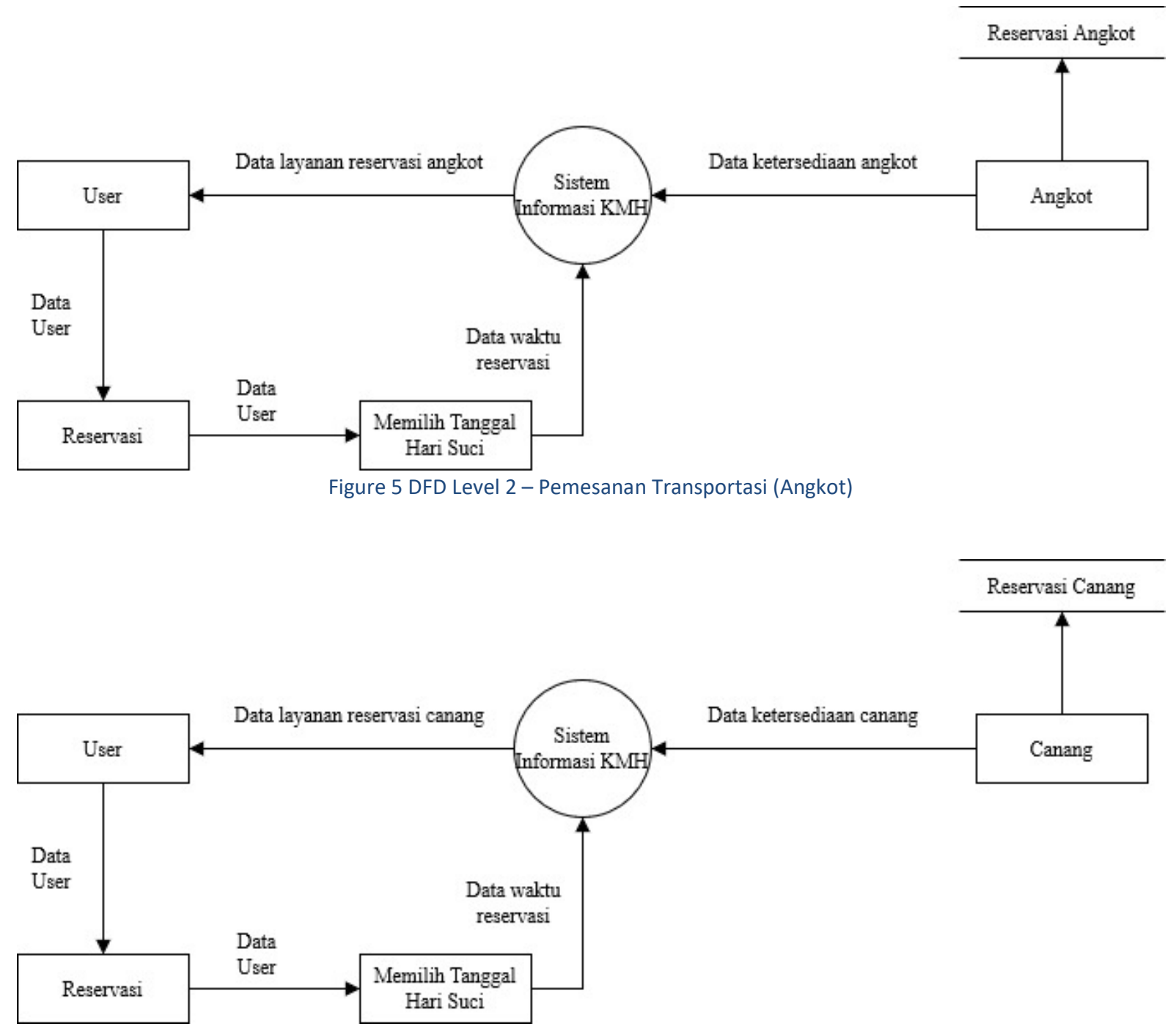

Figure 6 DFD Level 2 - Pemesanan Sarana Persembahyangan (Canang) 


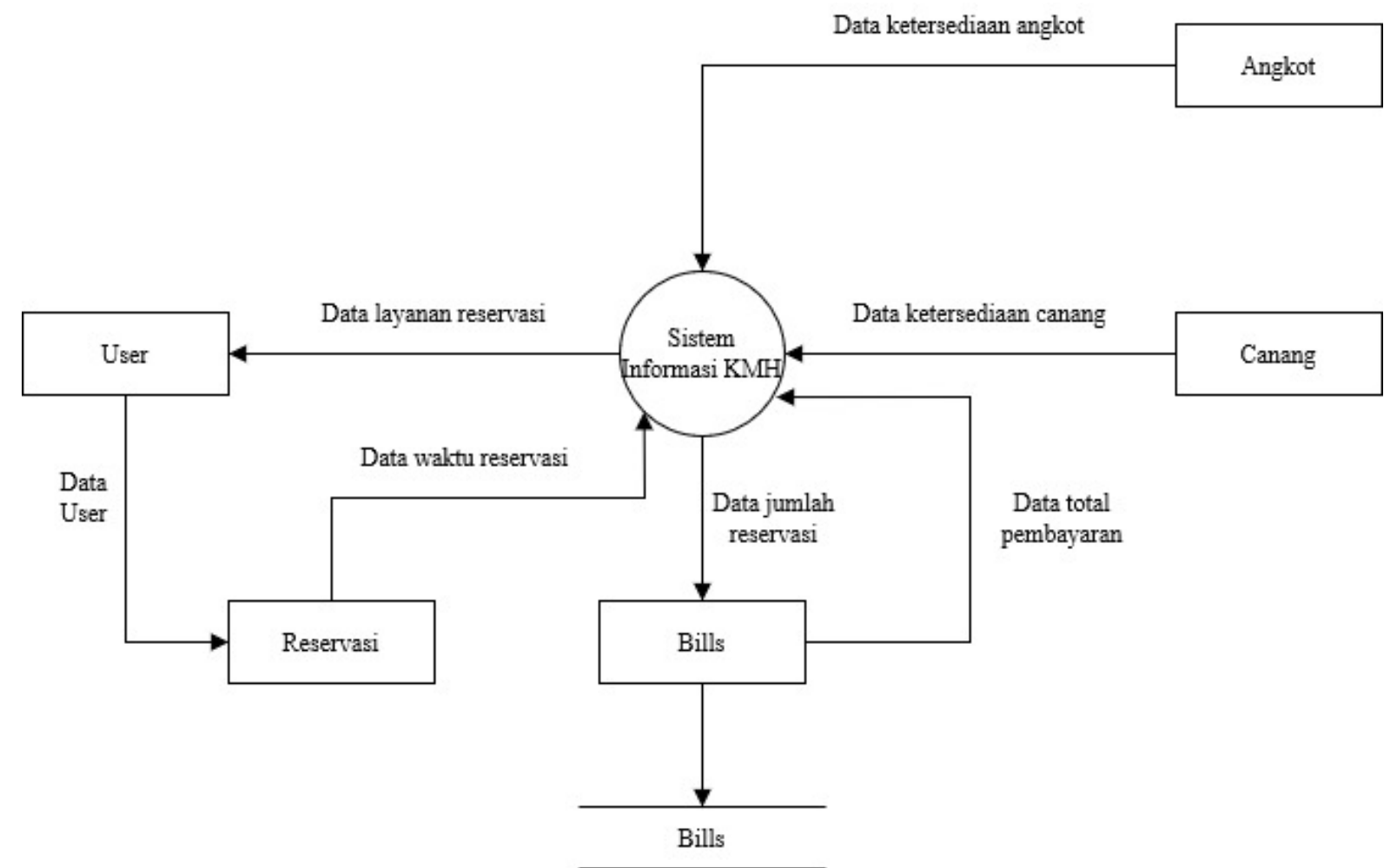

Figure 7 DFD Level 2 - Bills

\subsection{Entity Relationship Diagram (ERD)}

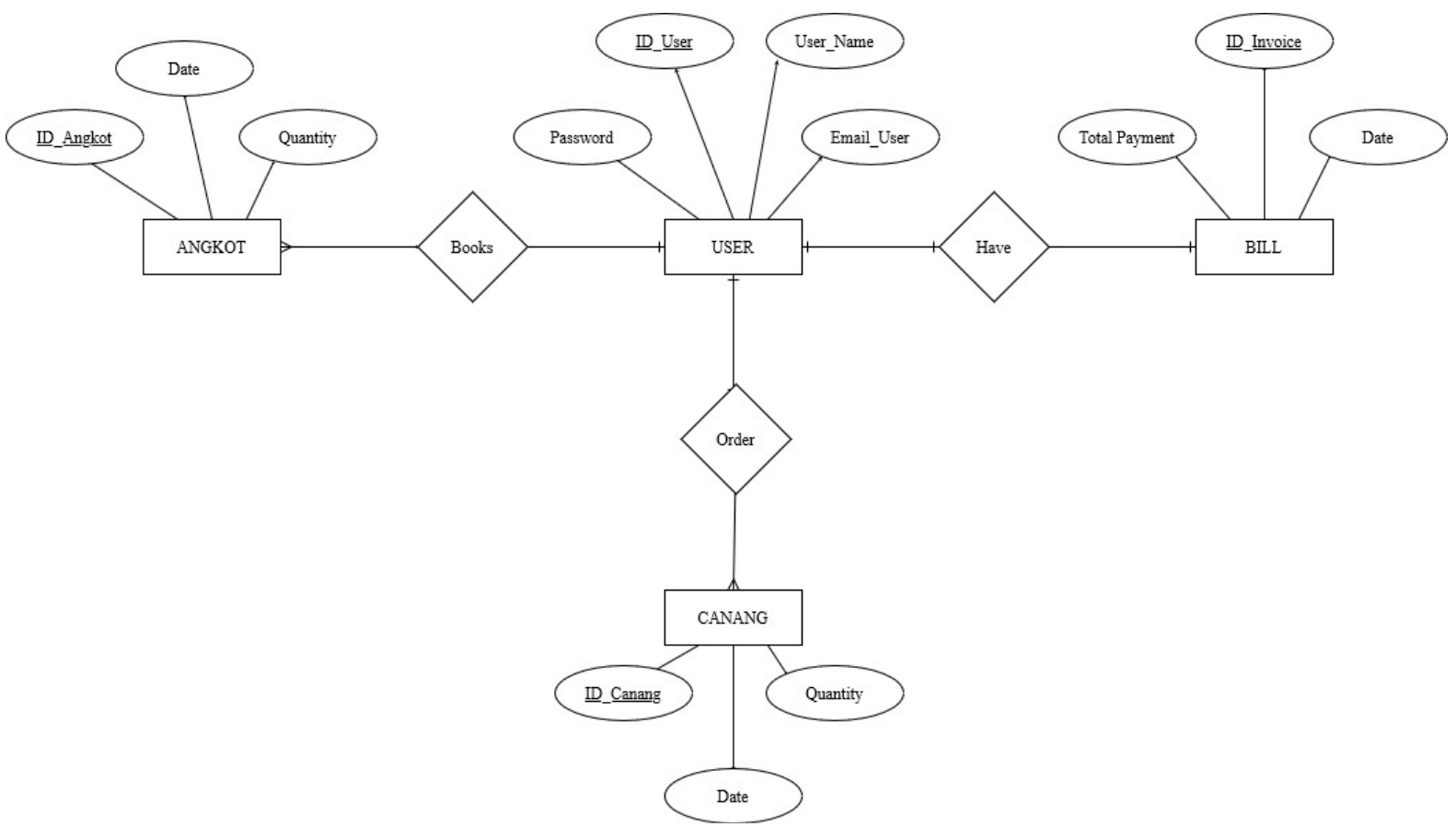

Figure 8 Entity Relationship Diagram

Entity relationship diagram menunjukkan hubungan antar entitas yang terdapat dalam sistem informasi, dalam hal ini terdapat empat entitas utama yaitu angkot, user, canang, dan bills. User merupakan pengguna sistem informasi, dimana setiap user nanti akan memiliki atribut yang terdiri atas User_Name, Email_User, ID_User, dan Password. Angkot merupakan fitur untuk reservasi transportasi, angkot memiliki beberapa atribut yaitu date untuk menentukan tanggal reservasi, ID_angkot, serta quantiy untuk menentukan jumlah kursi yang ingin dipesan. Canang merupakan 
entitas untuk pemesanan sarana persembahyangan. Canang memiliki beberapa atribut yaitu ID_canang, quantity, dan date. Bill merupakan entitas yang menunjukkan total pembayaran yang harus dibayarkan oleh pengguna sistem informasi atas pemesanan yang telah dilakukan. Bills memiliki atribut yang terdiri atas ID_Invoice, Date, dan Total payment.

\subsection{Database Design}

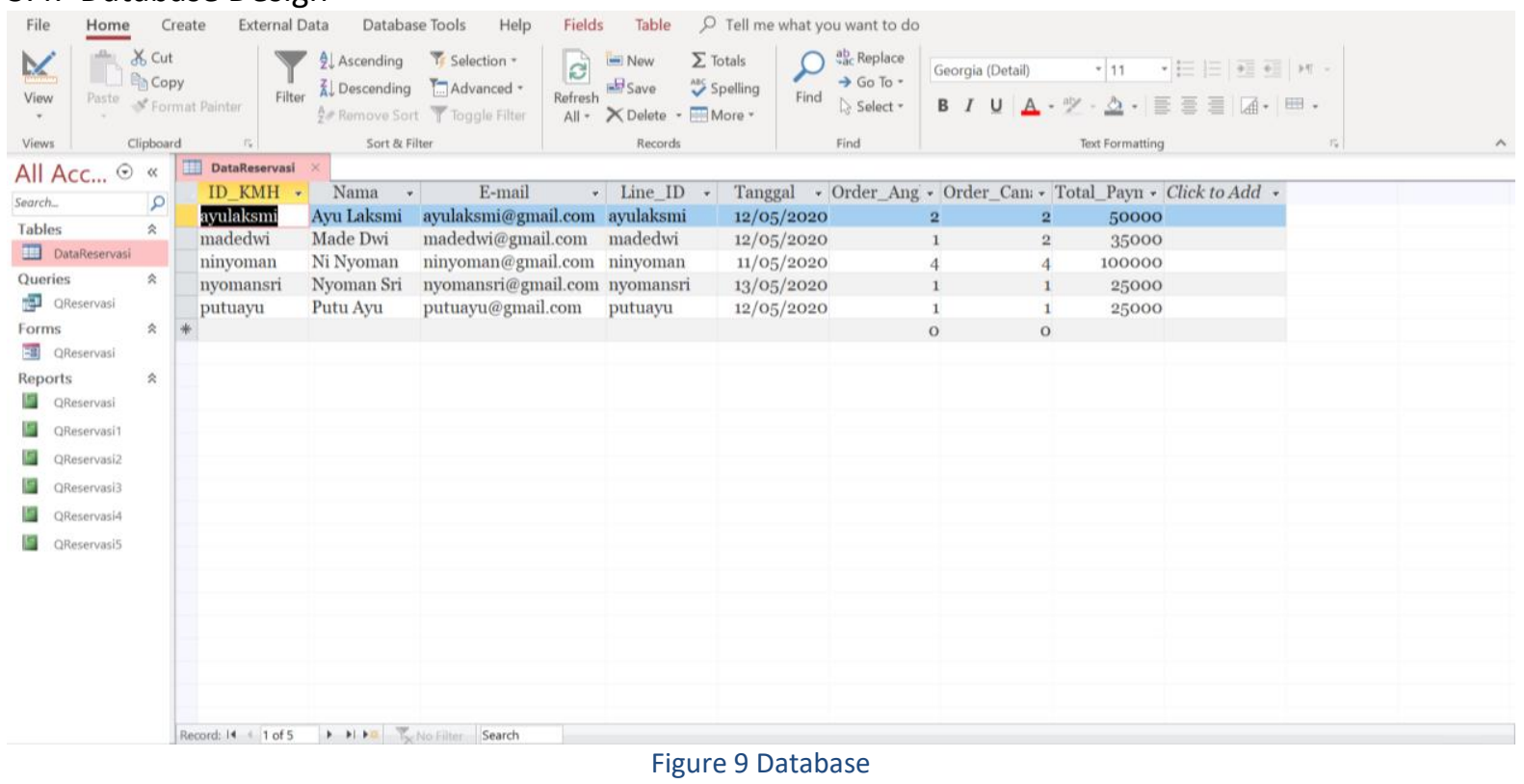

Semua data yang diisi pada form yang telah disubmit akan masuk ke database, figure 8 merupakan contoh dari database, dimana pada database tersebut terlihat semua user_id, nama, email, kontak line, tanggal pemesanan serta total biaya untuk pemesanan yang dilakukan. 


\subsection{Use Case Diagram}

Use Case Diagram digunakan untuk menggambarkan hubungan antara aktor dengan sistem. Dalam kasus ini aktor (mahasiswa anggtoa $\mathrm{KMH}$ ) dapat menggunakan sistem untuk login serta melakukan pemesanan transportasi (angkot) dan sarana ibadah (canang) pada sistem informasi. Pemesanan dilakukan dengan cara mengisi form yang disediakan, pada form tersebut mahasiswa dapat menentukan sarana yang ingin di pesan baik itu angkot atau canang, mahasiswa juga dapat menentukan kuantitas pemesanan yang diinginkan. Setelah itu sistem informasi akan menampilkan total payment yang harus dibayar dari pemesanan yang dilakukan.

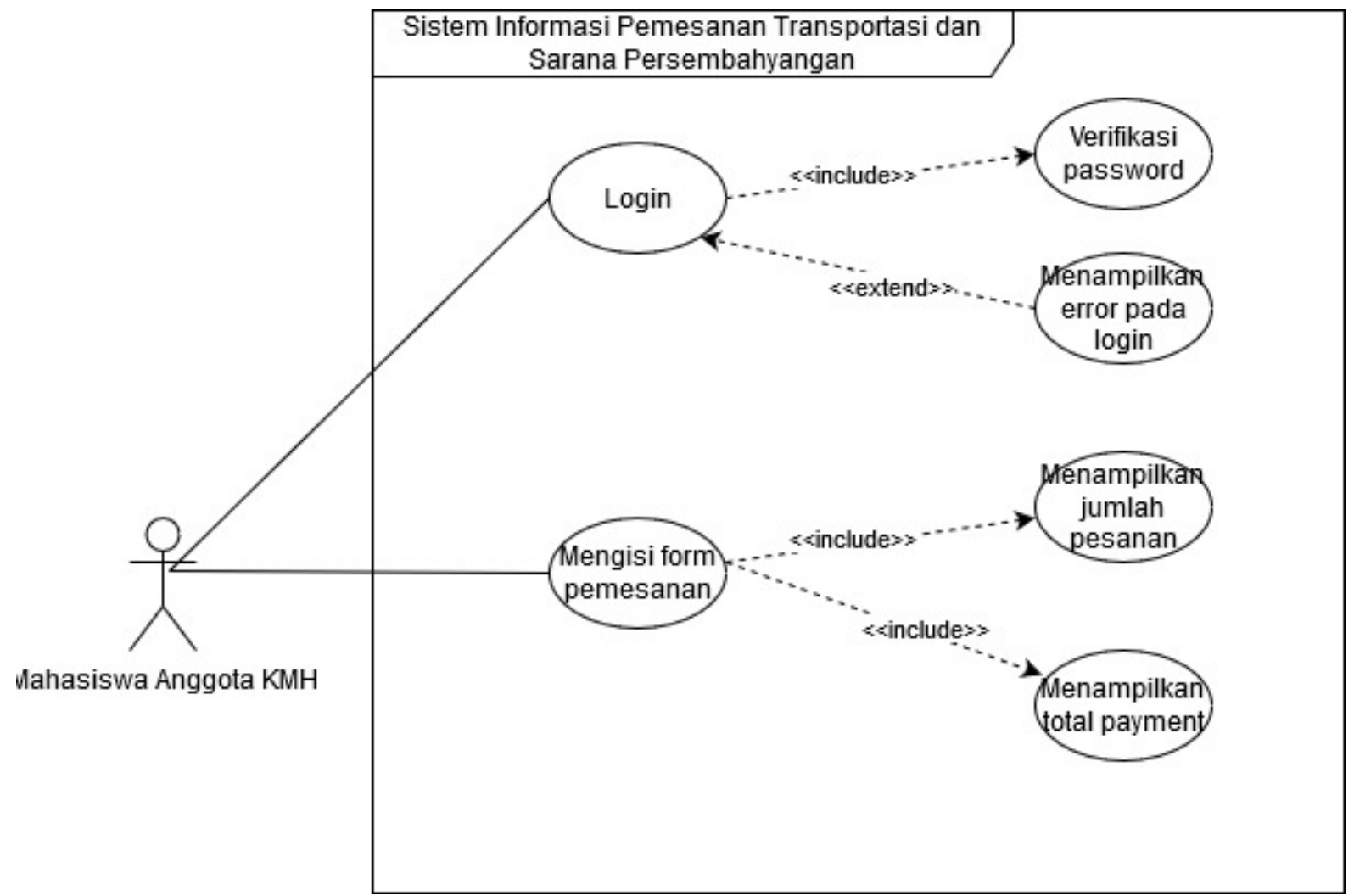

Figure 10 Use Case Diagram 


\subsection{Activity Diagram}

Activity diagram menunjukkan aliran aktivitas yang terjadi dalam sistem informasi. Dalam kasus ini aliran informasi diawali dengan mahasiswa anggota KMH yang melakukan akses pada website (sistem informasi) pemesanan, kemudian dapat melakukan login dengan ID KMH setiap anggota, jika log in berhasil maka website (sistem informasi) akan menampilkan form pemesanan, namun jika login gagal maka mahasiswa harus melakukan log in ulang. Setelah website menampilkan form pemesanan, maka selanjutnya mahasiswa melakukan pengisian data diri, fasilitas yang ingin dipesan serta kuantitasnya. Jika sudah maka sistem akan melakukan kalkulasi dan menampilkan total payment yang harus dibayarkan. Setelah itu mahasiswa dapat memilih button "Make order" untuk menyimpan pemesanan. Jika mahasiswa ingin melakukan pemesanan baru lagi maka dapat memilih "Create new" dan melakukan langkah-langkah yang sama seperti sebelumnya hingga memilih button "make order".

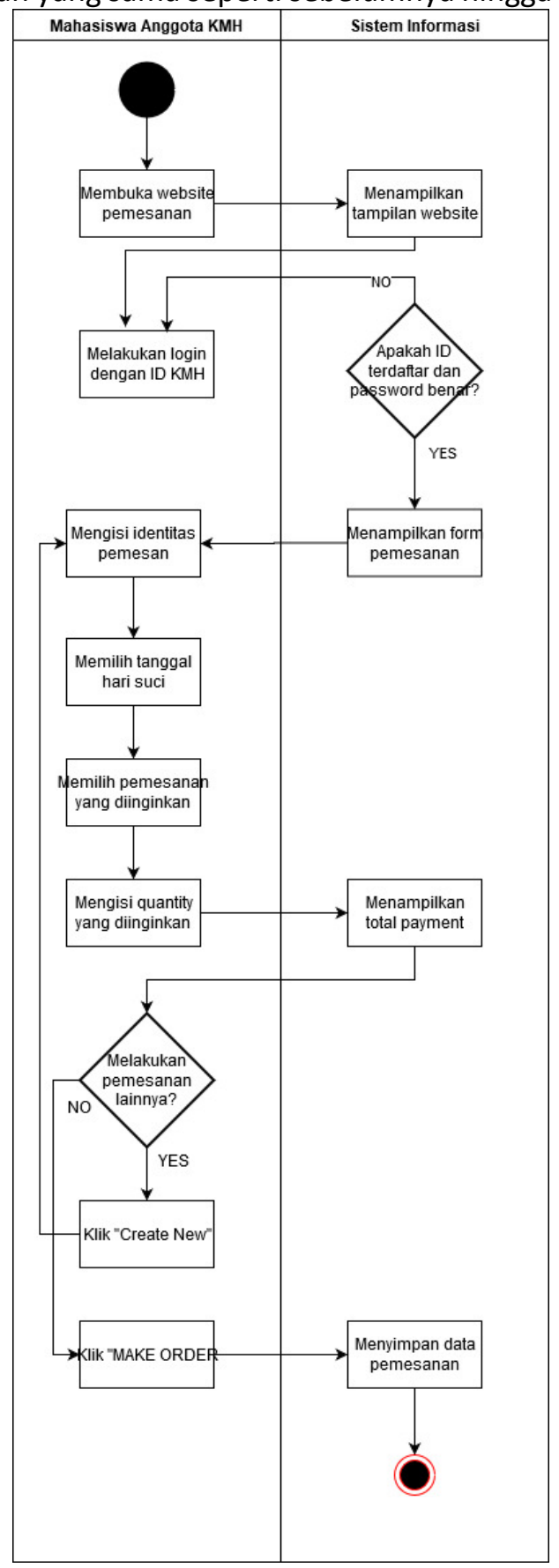

Figure 11 Activity Diagram 


\subsection{Sequence Diagram}

Sequence diagram merupakan bagian dari UML yang menggambarkan kolaborasi dinamis antar objek.Berikut merupakan sequence diagram dari fungsi pemesanan. Setelah mahasiswa melakukan pengisian data pemesanan pada reservation form maka akan dilanjutkan dengan processing request ke process reservation yang kemudian menyimpan data pemesanan ke database. Setelah itu data akan dikirimkan lagi dari data base ke process reservation dan pada bagian reservation form nanti akan muncul hasil kalkulasi payment yang harus dibayar oleh mahasiswa.

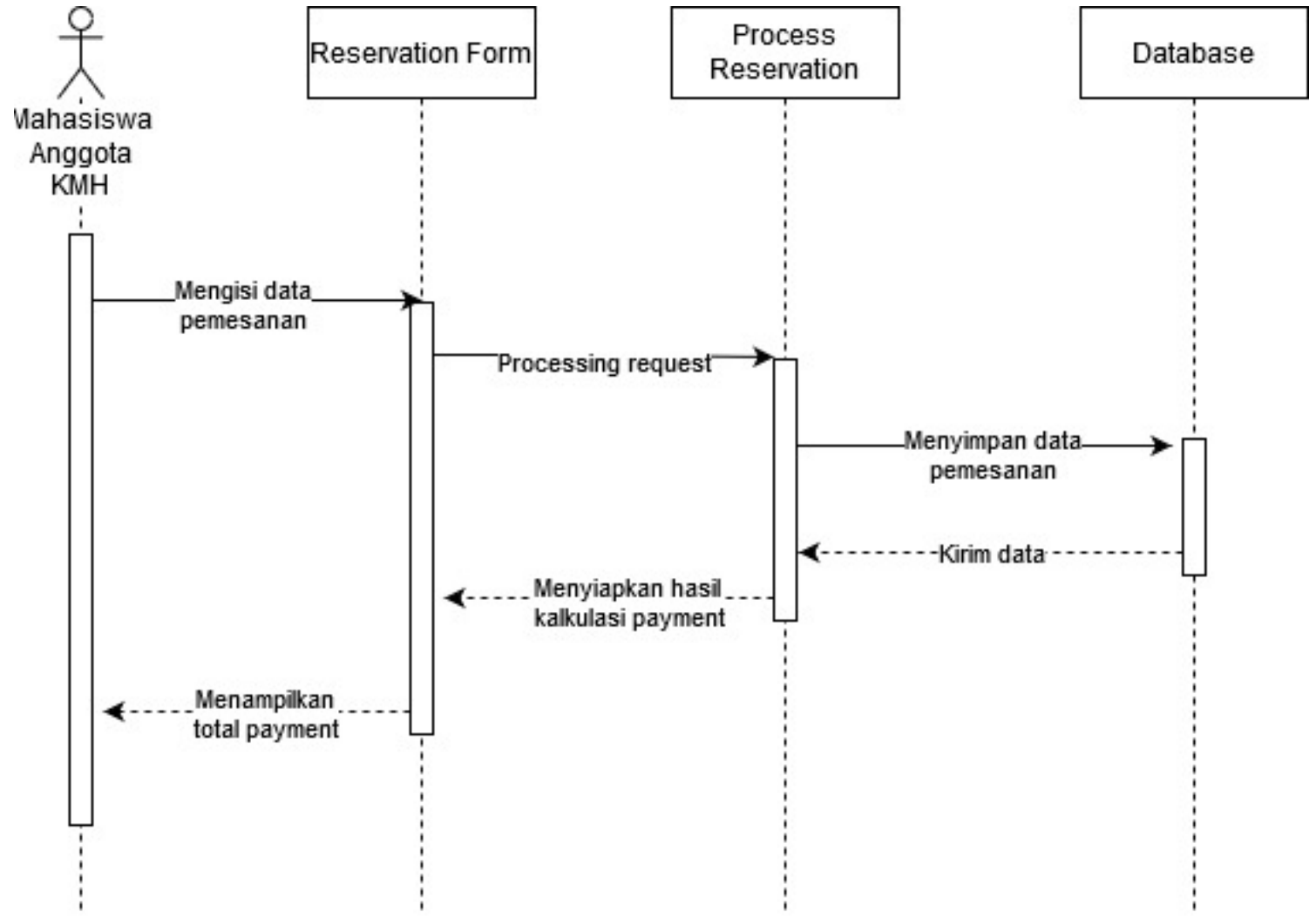

Figure 12 Sequence Diagram 
3.8 Interface Design

Gambar berikut merupakan tampilan dari interface design pada sistem informasi yang dirancang dengan menggunakan software Ms. Access yaitu form dan report.

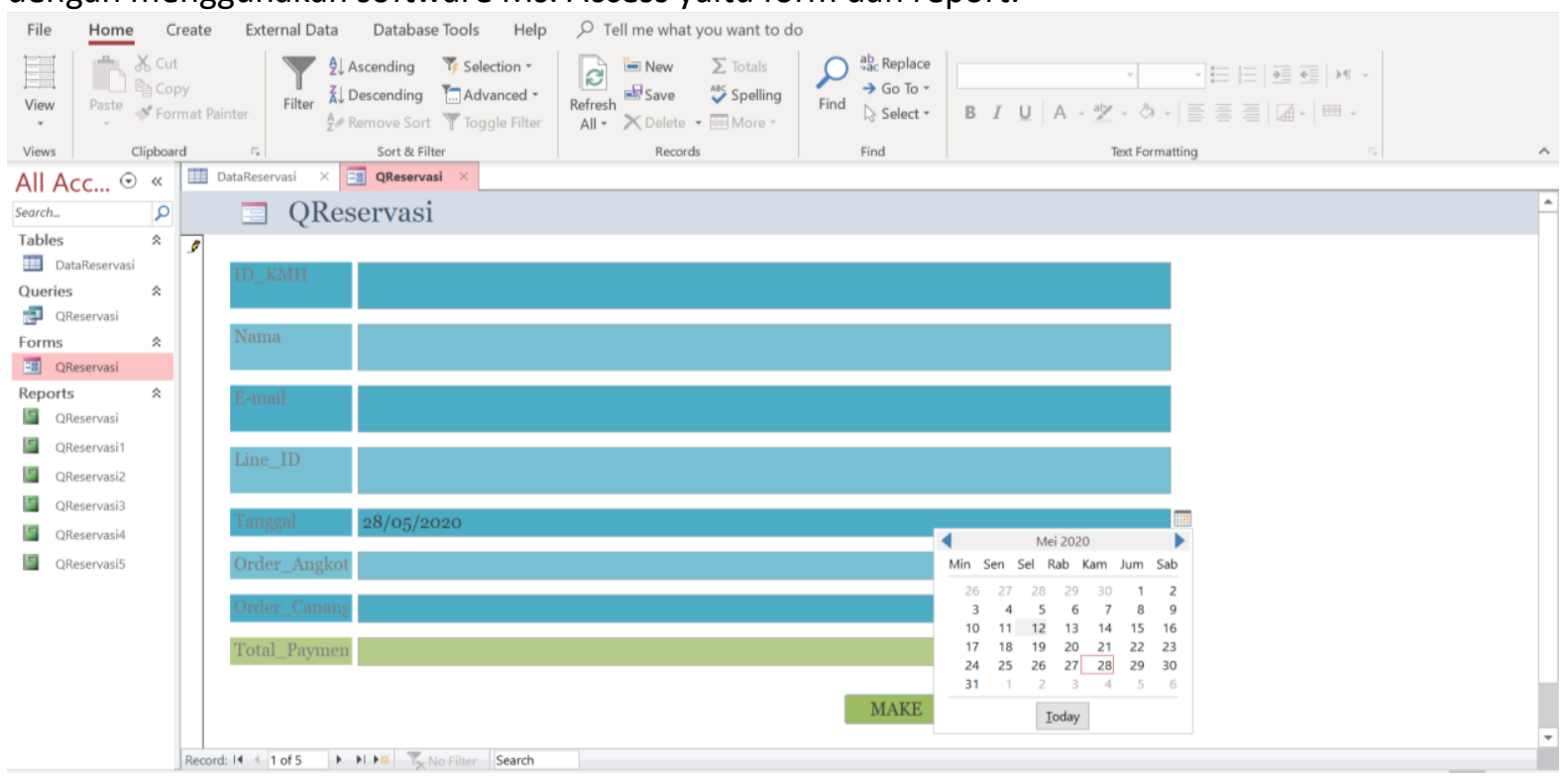

Figure 13 Tampilan form

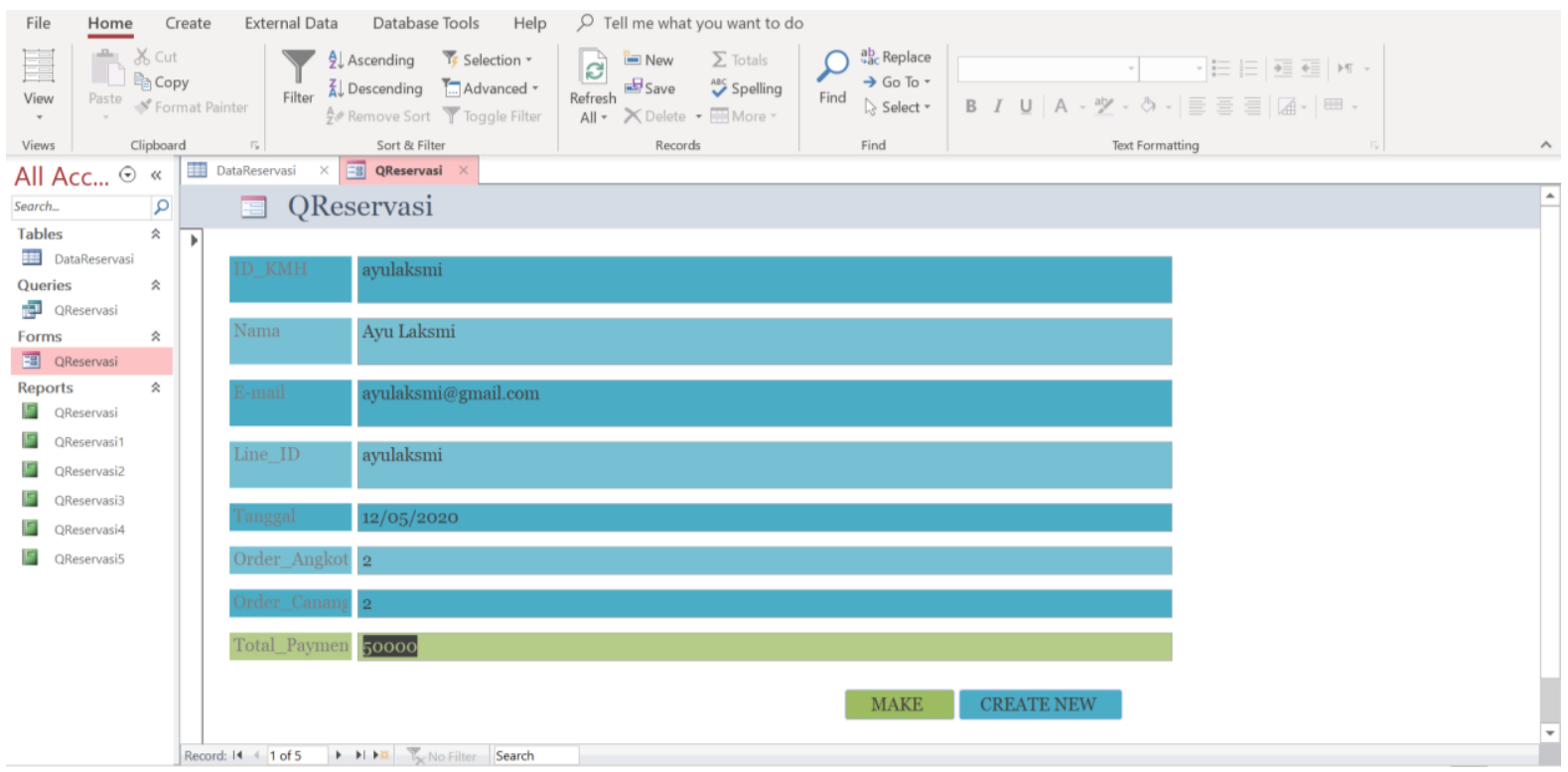

Figure 14 Tampilan form yang telah diisi 


\begin{tabular}{|c|c|c|c|c|c|c|}
\hline Q QReservasi & \multicolumn{6}{|c|}{$\begin{array}{r}\text { Kamis, } 28 \text { Mei } 2020 \\
11.36 .14\end{array}$} \\
\hline ID_KMH & Nama & \multicolumn{2}{|l|}{ E-mail } & \multicolumn{2}{|l|}{ Line_ID } & Tanggal \\
\hline ayulaksmi & Ayu Laksmi & \multicolumn{2}{|c|}{ ayulaksmi@gmail.com } & \multicolumn{2}{|c|}{ ayulaksmi } & $12 / 05 / 2020$ \\
\hline putuayu & Putu Ayu & \multicolumn{2}{|c|}{ putuayu@gmail.com } & \multicolumn{2}{|l|}{ putuayu } & $12 / 05 / 2020$ \\
\hline madedwi & Made Dwi & \multicolumn{2}{|c|}{ madedwi@gmail.com } & \multicolumn{2}{|l|}{ madedwi } & $12 / 05 / 2020$ \\
\hline nyomansri & Nyoman Sri & \multicolumn{2}{|c|}{ nyomansri@gmail.com } & \multicolumn{2}{|c|}{ nyomansri } & $13 / 05 / 2020$ \\
\hline ninyoman & Ni Nyoman & \multicolumn{2}{|c|}{ ninyoman@gmail.com } & \multicolumn{2}{|l|}{ ninyoman } & $11 / 05 / 2020$ \\
\hline \multicolumn{6}{|c|}{ Page 1 of 1} & \\
\hline \multicolumn{7}{|c|}{ Kamis, 28 Mei 2020} \\
\hline E-mail & Line_ID & Tanggal & Order_Angkot & Order_Canang & Total_Payment & \\
\hline ayulaksmi@gmail.com & ayulaksmi & $12 / 05 / 2020$ & 2 & 2 & 50000 & \\
\hline putuayu@gmail.com & putuayu & $12 / 05 / 2020$ & 1 & 1 & 25000 & \\
\hline madedwi@gmail.com & madedwi & $12 / 05 / 2020$ & 1 & 2 & 35000 & \\
\hline nyomansri@gmail.com & nyomansri & $13 / 05 / 2020$ & 1 & 1 & 25000 & \\
\hline ninyoman@gmail.com & ninyoman & $11 / 05 / 2020$ & 4 & 4 & 100000 & \\
\hline
\end{tabular}

Figure 15 Tampilan Report

\subsection{Source Code}

Gambar berikut merupakan tampilan back-end dari sistem informasi yang dirancang dengan software Ms. Access

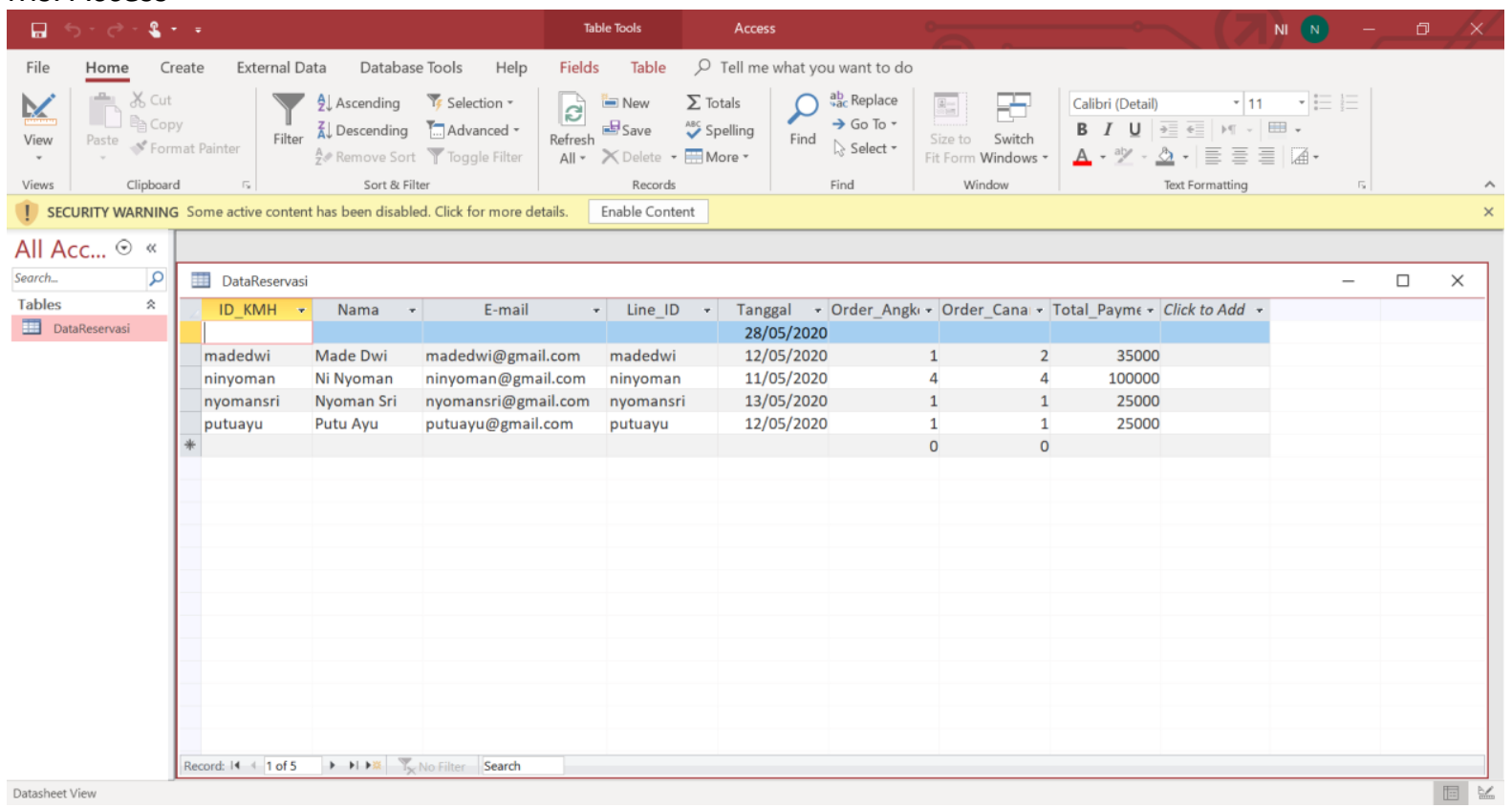

Figure 16 Tampilan Back-End pada Ms. Access 


\section{Penutup}

4.1 Kesimpulan

Sistem informasi berbasis web ini memiliki fungsi utama untuk melakukan reservasi atau pemesanan fasilitas yang berupa transportasi dan sarana ibadah yang diharapkan akan mempermudah mahasiswa umat Hindu yang sedang menempuh pendidikan di Telkom University untuk dapat melangsungkan ibadah pada hari-hari suci di Pura karena cukup jauhnya jarak pura dan cukup sulitnya menemukan sarana ibadah. Website ini nantinya akan dikelola oleh pengurus unit kegiatan mahasiswa Keluarga Mahasiswa Hindu Universitas Telkom yang bekerjasama dengan pihak pura untuk pemesanan sarana ibadah. Dengan adanya website ini mahasiswa akan lebih mudah untuk melakukan ibadah sehingga jumlah mahasiswa yang melakukan ibadah di Pura pada hari suci pun akan meningkat.

\subsection{Saran}

Paper ini masih dibuat dalam bentuk rancangan sistem informasi dan hanya dirancang dengan menggunakan software Ms. Access. Maka dari itu masih terdapat banyak kekurangan yang terdapat dalam paper ini untuk diwujudkan menjadi sistem informasi berbentuk website yang nyata. Maka dari itu jika kedepannya ada yang memungkinkan untuk menambahkan rancangan sistem informasi ini dan mewujudkannya menjadi sistem informasi yang nyata saya akan sangat mengapresiasi.

\section{References}

[1] R. Aurachman, "Review Terhadap OSF.IO Sebagai Sarana Publikasi Preprint," OSF Preprints, 17 May 2020.

[2] R. Aurachman, "Kerangka Perancangan Sistem Informasi Sebagai Pembelajaran Mahasiswa Teknik Industri," osf.io, 52020.

[3] R. Aurachman, "Analisis dan Perancangan Sistem Informasi", Available: https://www.youtube.com/watch?v=tVMI4Z8UGoo\&list=PLxYRczqMg8QpugF4mfss OPZoT4vn4 C1k

\section{Additional}

[a] R. Aurachman, "Review Terhadap OSF.IO Sebagai Sarana Publikasi Preprint," OSF Preprints, 17 May 2020. doi:10.31219/osf.io/rvumx , Available: https://osf.io/rvumx

[b] R. Aurachman, "Kerangka Perancangan Sistem Informasi Sebagai Pembelajaran Mahasiswa Teknik Industri," osf.io, doi:10.31219/osf.io/tmpen , 5 2020. Available: https://osf.io/tmpcn

[c] Dina, Y.A., "Contoh Sequence Diagram", 11 May 2020. Available: https://ngampus.id/contohsequence-diagram/

[d] Hutauruk, M. K., “UML Diagram: Use Case Diagram”, 26 November 2019. Available: https://socs.binus.ac.id/2019/11/26/uml-diagram-use-case-diagram/

[e] Nuroji, "Metode-metode Pengembangan Sistem Informasi", 2 April 2017. Available: https://nuroji.uhamka.ac.id/1641-2/

[f] Rizky, M., "UML Diagram: Activity Diagram", 22 November 2019. Available: https://socs.binus.ac.id/2019/11/22/uml-diagram-activity-diagram/ 